\title{
Photoelectrochemical solar cell using extract of Eugenia jambolana Lam as a natural sensitizer
}

\author{
CHRISTIAN G. GARCIA, ANDRÉ S. POLO and NEYDE Y. MURAKAMI IHA \\ Instituto de Química, Universidade de São Paulo, 05508-900 São Paulo, SP, Brasil \\ Manuscript received on November 26, 2002; accepted for publication on April 2, 2003; \\ presented by FERNANDO GALEMBECK
}

\begin{abstract}
The extract of Jambolão (java plum), Eugenia jambolana Lam, was used as a natural sensitizer of a wide band-gap semiconductor $\left(\mathrm{TiO}_{2}\right)$ in photoelectrochemical solar cells. The natural dye, adsorbed onto the semiconductor surface, absorbs visible light and promotes electron transfer across the dye/semiconductor interface. Photogenerated current and voltage as high as $2.3 \mathrm{~mA}$ and $711 \mathrm{mV}$, respectively, were obtained and effective conversion of visible light into electricity was achieved. The use of a natural product as the semiconductor sensitizer enables a faster and simpler production of cheaper and environmentally friendly solar cells.
\end{abstract}

Key words: photoelectrochemical solar cell, natural dye, Jambolão (java plum), energy conversion, dye sensitized solar cells.

Dye sensitized photoelectrochemical solar cells are devices for the conversion of visible light into electricity based on sensitization of wide band-gap semiconductors (Grätzel 2001, Murakami Iha et al. 2003). The sensitization approach enables the generation of electricity with irradiation energy lower than the band-gap of the semiconductor. The main progress of such devices occurred after the development of nanostructured porous semiconductor films onto which light absorbing dye molecules are adsorbed. Synthetic inorganic dyes, such as ruthenium(II) complexes with carboxylated polypyridyl ligands, are commonly employed as molecular sensitizers in such cells (Bignozzi et al. 1997, Murakami Iha et al. 1998, Murakami Iha 2000). Other approaches, such as the use of natural extracts (Cherepy et al. 1997, Tennakone et al. 1997, Smes-

Correspondence to: Neyde Y. Murakami Iha E-mail: neydeiha@iq.usp.br tad 1998, Smestad and Grätzel 1998, Dai and Rabani 2001, 2002a, b), have also been reported. Our work has been conducted using synthetic inorganic dyes as semiconductor sensitizers (Garcia et al. 1998a, b, 2000, 2002a, b, Garcia and Murakami Iha 2001a, b). Here we report the use of extract of Jambolão fruit (java plum), Eugenia jambolana Lam, as a natural sensitizer in photoelectrochemical solar cells.

Jambolão, also known as jamelão, jambul, or jambeiro, is the fruit of a well-disseminated tropical tree, commonly found in the northeast of Brazil. The violet juice extracted from the fresh fruit presents intense broad bands in the visible region of the electronic spectrum (Figure 1). The use of a natural dye, obtained from Jambolão extract, as the molecular sensitizer of nanostructured $\mathrm{TiO}_{2}$ films results in purplish-violet colored photoanodes, which are employed in photoelectrochemical solar cells.

The experiments were carried out in sandwich- 


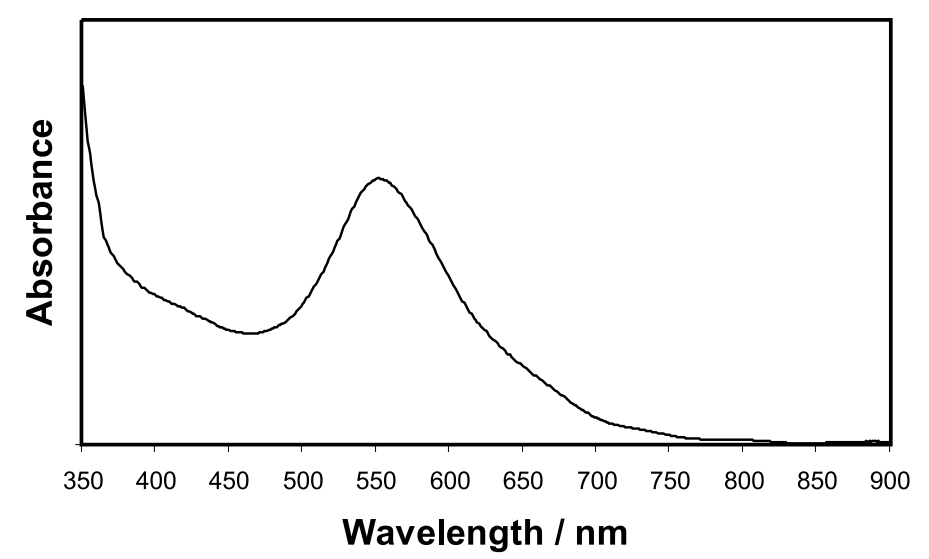

Fig. 1 - Electronic spectrum of a photoanode sensitized by Eugenia jambolana Lam.

type photoelectrochemical solar cells, consisted by a photoanode, a counter-electrode and an electrolyte mediator layer in between. Both electrode substrates are glasses covered by a conducting film: FTO (Fluorine doped Tin Oxide) for photoanode and ITO (Indium doped Tin Oxide) for counter-electrode. The mediator layer is the $\mathrm{I}^{-} / \mathrm{I}_{3}^{-}$solution (acetonitrile/3methyl-2-oxazolidinone (90:10)). The transparent photoanode was prepared by the deposition of a $\mathrm{TiO}_{2}$ semiconductor film, prepared from titanium isopropoxide, followed by the sintering of its particles at $450^{\circ} \mathrm{C}$ and having the dye adsorbed on the surface of nanosized oxide. Fruit extracts was obtained squeezing fresh Jambolão fruits.

The performance of this natural dye as the semiconductor sensitizer was monitored through the current and voltage output upon light irradiation of a photoelectrochemical solar cell with an effective area of $0.5 \mathrm{~cm}^{2}$. Photocurrent and photovoltage values as high as $2.3 \mathrm{~mA}$ and $711 \mathrm{mV}$, respectively, were obtained with overhead projector light irradiation. Such values are similar to those obtained employing traditional synthetic dyes (Grätzel 2001). The results show that the extract of Jambolão, adsorbed onto the semiconductor surface, acts as a good sensitizer and efficiently promotes electron transfer across the dye/semiconductor interface.
Effective conversion of visible light into electricity was achieved with the use of extract of Jambolão as the semiconductor sensitizer in photoelectrochemical solar cells. The use of a natural product enables a faster, simpler and environmentally friendly solar cell production without the requirement of all steps involved in the preparation and purification of synthetic dyes. Nevertheless, stability and long-term operation are fundamental issues for the development of such devices and further studies are in progress.

\section{ACKNOWLEDGMENTS}

The authors are grateful to FAPESP and CNPq for the financial support.

\section{RESUMO}

O extrato de Jambolão, Eugenia jambolana Lam, foi utilizado como um sensibilizador natural de um semicondutor com separação grande de bandas $\left(\mathrm{TiO}_{2}\right)$ nas células solares fotoeletroquímica. O corante natural, adsorvido na superfície do semicondutor, absorve luz visível e promove transferência eletrônica na interface corante/semicondutor. A corrente e o potencial fotogerados tão altos como $2,3 \mathrm{~mA}$ e $711 \mathrm{mV}$, respectivamente, foram obtidos observando-se conversão eficiente de luz visível em 
eletricidade. O uso de um produto natural como o sensibilizador de semicondutor possibilita uma produção mais rápida e simples de células solares mais baratas que não agridem o meio ambiente.

Palavras-chave: célula solar fotoeletroquímica, corante natural, Jambolão, conversão de energia, células solares sensibilizadas por corante.

\section{REFERENCES}

Bignozzi CA, Schoonover JR And Scandola F. 1997. A supramolecular approach of light-harvesting and sensitization of wide-bandgap semiconductors: Antenna effects and charge separation. Prog Inorg Chem 44: $1-95$.

Cherepy NJ, Smestad GP, Grätzel M And Zhang JZ. 1997. Ultrafast electron injection: Implications for a photoelectrochemical cell utilizing an anthocyanin dye-sensitized $\mathrm{TiO}_{2}$ nanocrystalline electrode. J Phys Chem B 101: 9342-9351.

DaI Q AND Rabani J. 2001. Photosensitization of nanocrystalline $\mathrm{TiO}_{2}$ films by pomegranate pigments with unusually high efficiency in aqueous medium. Chem Commun 20: 2142-2143.

Dai Q and Rabani J. 2002a. Photosensitization of nanocrystalline $\mathrm{TiO}_{2}$ films by anthocyanin dyes. J Photochem Photobiol A 148: 17-24.

Dai Q AND Rabani J. 2002b. Unusually efficient photosensitization of nanocrystalline $\mathrm{TiO}_{2}$ films by pomegranate pigments in aqueous medium. New $\mathbf{J}$ Chem 26: 421-426.

Garcia CG and Murakami Iha NY. 2001a. Photoelectrochemical solar cells using [ $\left.\left(\mathrm{dcbH}_{2}\right)_{2} \mathrm{RuLL}^{\prime}\right]$, L,L' = substituted pyridines, as nanocrystalline $\mathrm{TiO}_{2}$ sensitizers. Int J Photoenergy 3: 131-135.

Garcia CG and Murakami Iha NY. 2001b. An interdisciplinary experience on the development of Dye-Cell technology. Int J Photoenergy 3: 137-141.

Garcia CG, Murakami Iha NY, Argazzi R and BigNOZZI CA. 1998a. Sensitization of n-Type $\mathrm{TiO}_{2}$ Electrode by a Novel Isoquinoline Ruthenium(II) Polypyridyl Complex. J Braz Chem Soc 9: 13-15.
Garcia CG, Murakami Iha NY, Argazzi R and BigNOZZI CA. 1998b. 4-Phenylpyridine as ancillary ligand in ruthenium(II) polypyridyl complexes for sensitization of n-type $\mathrm{TiO}_{2}$ electrodes. J Photochem Photobiol A 115: 239-242.

Garcia CG, de Lima JF and Murakami Iha NY. 2000. Energy conversion: from the ligand field photochemistry to solar cells. Coord Chem Rev 196: 219-247.

Garcia CG, KleverlaAn CJ, Bignozzi CA and MuraKami Iha NY. 2002a. Time-resolved experiments in dye-sensitized solar cells using $\left[\left(\mathrm{dcbH}_{2}\right)_{2}\right.$ $\left.\mathrm{Ru}(\text { ppy })_{2}\right]\left(\mathrm{ClO}_{4}\right)_{2}$ as a nanocrystalline $\mathrm{TiO}_{2}$ sensitizer. J Photochem Photobiol A 147: 143-148.

Garcia CG, Nakano AK, Kleverlaan CJ and MuRAKAMI IHA NY. 2002b. Electron injection vs. charge recombination in photoelectrochemical solar cells using cis-[(dcbH$\left.)_{2} \mathrm{Ru}(\mathrm{CNpy})\left(\mathrm{H}_{2} \mathrm{O}\right)\right] \mathrm{Cl}_{2}$ as nanocrystalline $\mathrm{TiO}_{2}$ sensitizer. J Photochem Photobiol A 151: 165-171.

GrÄtzel M. 2001. Photoeletrochemical cells. Nature 414: 338-344.

Murakami Iha NY. 2000. Supramolecular Photochemistry and Solar Cells. An Acad Bras Cienc 72: 67-73.

Murakami Iha NY, Nakano AK and Garcia CG. 1998. Fotoquímica Inorgânica na Conversão de Energia Solar. Anais Assoc Bras Quím 47: 46-56.

Murakami Iha NY, Garcia CG and Bignozzi CA. 2003. Dye-Sensitized Photoelectrochemical Solar Cells. Nalwa HS (Ed.), Handbook of Photochemistry and Photobiology, American Scientific Publishers, in press.

SMESTAD GP. 1998. Education and solar conversion: Demonstrating electron transfer. Sol Energy Mater Sol Cells 55: 157-178.

Smestad GP AND Grätzel M. 1998. Demonstrating electron transfer and nanotechnology: A natural dyesensitized nanocrystalline energy converter. J Chem Educ 75: 752-756.

Tennakone K, Kumarasinghe AR, Kumara GRRA, WiJAYANTHA KGU AND SiRimanne PM. 1997. Nanoporous $\mathrm{TiO}_{2}$ photoanode sensitized with the flower pigment cyanidin. J Photochem Photobiol A 108: 193-195. 